$\begin{array}{llll}\text { AL-Qadisiya Journal of Vet.Med.Sci. } & \text { Vol./11 } & \text { No./1 }\end{array}$

\title{
Papillomatosis in Iraqi camels
}

\author{
M. H. Hussain \\ F. G. Habasha \\ S. A. Hasso
}

Coll. of Vet. Med./ Unive. of Al-Qadissiya Coll. of Vet. Med./ Unive. of Baghdad

\section{Abstract}

The survey began in December 2008 and finished in June 2009 in three governorates; Al-Qadissiya, Al-Najaf and Al-Muthanna in different locations inspecting 2412 dromedaries, we found 102 affected camels with papilloma, samples were carried out to detect the papillomatosis histologically which present $4.2 \%$ of the total inspected camels. There was an obvious agedepending infection; papillomatosis was diagnosed in $77.5 \%$ of camels ranged in 5-10 years old and $22.5 \%$ of camels more than 10 years old and $0 \%$ in camels less than 5 years old.

\section{Introduction}

Papillomas (warts) are benign neoplastic growths of the skin and mucous membranes and are observed worldwide in humans and a variety of animals. They are caused by species-specific papillomaviruses that have also been associated with the development of squamous cell carcinoma. More than 70 papillomaviruse serotypes are recognized in humans and cattle, while only 1 virus type has so far been identified in each of the other animal species. The papillomaviruses can also affect camels and cause typical skin lesions $(1 ; 2 ; 3 ; 4 ; 5$; 6).Solid outgrowth of epidermis that may be sessile or peduncular (7). In the early stages of papillomatosis, the lesions appear as rosy, hyperemic elevations of the skin. (1) described an outbreak of papillomatosis in Somalia where many dromedaries revealed pustules and scabs on lips and nostrils and generalized proliferative small and large nodules and tumor-like lesions. Some camels had lesions on the ears, eyelids, inguinal and genital regions and on their legs. The morbidity was high, but mortality

\section{Materials and Methods}

\section{I-Materials}

$10 \%$ formalin

Ammonia

Digital Camera

Distilled water

Ethanol $96 \%$

Glycerin

\section{II- Animals of the study}

Three governorates were involved in this research; Al-Qadissiya, Al-Najaf and Al-Muthanna, samples collected from the slaughter houses, sale yards and the herds found in several locations randomly. The research began on December 2008 and was illegible. Microscopically, the affected epithelium is hyperplastic with excessive folding that leads to the formation of proliferative outgrowths. The epithelial hyperplasia is characterized by marked acanthosis, para- and hyperkeratosis with elongation of the rete ridges. These ridges extend deep into the underlying dermal connective tissue, which might turn hyperplastic. Within the stratum granulosum individual and/or clusters of cells might appear with swollen, clear cytoplasm and large pleomorphic keratohyalin-like granules (hollow cells). Immunity usually develops 3-4 weeks after initial infection, but papillomatosis occasionally recurs, probably due to loss of immunity. Infectious papillomatosis is a self-limiting disease, although the duration of warts varies considerably. A variety of treatments have been advocated without agreement on efficacy. Surgical removal is recommended if the warts are sufficiently objectionable (7).

\author{
Haris Hematoxyline- eosin \\ Hydrochloric acid $\mathrm{HCl} 1 \%$ \\ Light microscope \\ Paraffin wax \\ Rotary microtome \\ Xylene
}

finished on June 2009. 2412 Iraqi dromedaries were examined regardless to location, age, sex and breed, from which 102 camels were suffering papillomatosis.

III- Diagnosis of Papillomatosis: camels inspected with focal solid overgrowth especially on the neck, and the papilloma 
was closed with different sizes up to $10 \mathrm{~cm}$ in diameter. Papilloma, after slaughter, kept in $10 \%$ formalin from affected camels and patched for the histopathological diagnosis in which microscopic feature showed thickening of the epithelium and proliferation of fibrous connective tissue (fibrosis) and depletion of hair follicles.

The procedure includes:

1- Fixation: first of all, it's better to wash the samples with water, after that, samples had fixed in $10 \%$ formalin for 6-12 hr.

2- Washing and dehydration: after fixing, samples should be washed with water 1-3 hr.. An ascending series of dehydration with ethanol; $70 \%, 80 \%, 90 \%$, and $100 \%$ in which two times of 1-2 hr. in each concentration respectively in order to have a complete dehydration.

3- Cleaning and embedding: using xylene to make tissue cleaning for about $0.5-2 \mathrm{hr}$.. Embedding has done by using Parafine wax in $58 \mathrm{C}^{\circ}$ prepared in the laboratory and dipping the tissues in two stages, left for 6$24 \mathrm{hr}$ to get solid.

4- Sectioning: solid blocks had sectioned by rotary microtome with $5-6 \mu \mathrm{m}$ in thickness. Each has transferred to a water bath fixed in $56 \mathrm{C}^{\circ}$. put the sections on clean slides in which thin smear of glycerin has prepared, after that the slides dried in air or using oven fixed in $40 \mathrm{C}^{\circ}$ for $12-24 \mathrm{hr}$. finally; each slide has dipped in xylene for 5 seconds to exclude the wax.

5- Staining: slides had overlaid with Haris Hematoxyline-eosin for 5 minutes, washed with water, rapid wash with $\mathrm{HCl}$ and the last stage is washing with water and left to be dried.

6- Reading: cover the slides with glassy covers and read the results using microscope with oil lens.Professional procedure suggests dipping the slides in ammonia to increase the brightness of the picture (8).

\section{Results and discussion}

As illustrated in table (1), papillomatosis has found in 102 camels with no report in camels less than 5 years old. Similar percentage has been found in both male and female, the disease was most common in camels in 5-10 years old (77.5\%). The commonest site of papilloma, as in fig (1), was the brisket and neck in which papilloma ranged in $3-10 \mathrm{~cm}$ in diameter, solid outgrowth, firm consistency, haired, adhered to subcutaneous tissue firmly, normal external color and seems to be 1-4 in each individuals. Camels having papillomatosis seem infebrile $(36.3 \pm 0.03) \quad \mathrm{C}^{\mathrm{o}}, \quad(15 \pm 0.5)$ respiratory rate, $(45 \pm 1.5)$ pulse rates, painless, no itching, good appetite, good ruminating, pink to light red mucous membrane and in some cases there were exudative epidermitis or ring worm infection in the same camel but in different site on the skin.Histopathological examination of papilloma preserved in 10\% formation gave the features of Hyperkeratosis, acanthosis (epidermal hyperplasia) and proliferation of fibrous connective tissue (fibrosis) and depletion of hair follicles as in fig (2).Another histological section in the skin affected with papillomatosis in fig (3) showed the proliferation of keratinized layer (hyperkeratosis) and thickening of epithelium, also there is proliferation of fibroblast along the skin, accentuation of the rete with edema and depletion of hair follicles. 
Table (1): Numbers of infected camels with papillomatosis according to the location, age and sex

\begin{tabular}{|c|c|c|c|c|c|c|c|c|}
\hline \multirow{2}{*}{\multicolumn{2}{|c|}{ Locations }} & \multirow{3}{*}{$\begin{array}{c}\text { Infected } \\
\text { camels }\end{array}$} & \multicolumn{2}{|c|}{$\sim 5$ years } & \multicolumn{2}{|c|}{ 5-10 years } & \multicolumn{2}{|c|}{ 10 years } \\
\hline & & & male & female & male & female & male & female \\
\hline \multirow{6}{*}{$\begin{array}{c}\text { Al- } \\
\text { Qadissyia }\end{array}$} & Slaughter house & & 0 & 0 & 3 & 3 & 1 & 0 \\
\hline & $\begin{array}{l}\text { Al-Hamza Al- } \\
\text { Shargy }\end{array}$ & 8 & 0 & 0 & 2 & 4 & 1 & 1 \\
\hline & Al-Daghara & 2 & 0 & 0 & 0 & 2 & 0 & 0 \\
\hline & Aal-Bdeer & 12 & 0 & 0 & 4 & 6 & 0 & 2 \\
\hline & Al-Shaf'ya & 0 & 0 & 0 & 0 & 0 & 0 & 0 \\
\hline & Al-Shenafeya & 17 & 0 & 0 & 5 & 7 & 2 & 3 \\
\hline \multirow{2}{*}{ Al-Najaf } & Slaughter house & 9 & 0 & 0 & 4 & 4 & 0 & 1 \\
\hline & Sale yard & 12 & 0 & 0 & 9 & 2 & 1 & 0 \\
\hline \multirow{3}{*}{$\begin{array}{c}\text { Al- } \\
\text { Muthanna }\end{array}$} & Slaughter house & 2 & 0 & 0 & 0 & 1 & 1 & 0 \\
\hline & Sale yard & 11 & 0 & 0 & 4 & 4 & 2 & 1 \\
\hline & Herds & 22 & 0 & 0 & 2 & 13 & 3 & 4 \\
\hline \multicolumn{2}{|l|}{ Total } & 102 & 0 & 0 & 33 & 46 & 11 & 12 \\
\hline \multicolumn{2}{|l|}{ Percentage } & & 0 & 0 & 32.6 & 45.1 & 10.8 & 11.8 \\
\hline \multicolumn{2}{|l|}{ Total } & & \multicolumn{2}{|c|}{0} & \multicolumn{2}{|c|}{79} & \multicolumn{2}{|c|}{23} \\
\hline \multicolumn{2}{|l|}{ Percentage } & & \multicolumn{2}{|c|}{0} & \multicolumn{2}{|c|}{77.5} & \multicolumn{2}{|c|}{22.5} \\
\hline
\end{tabular}

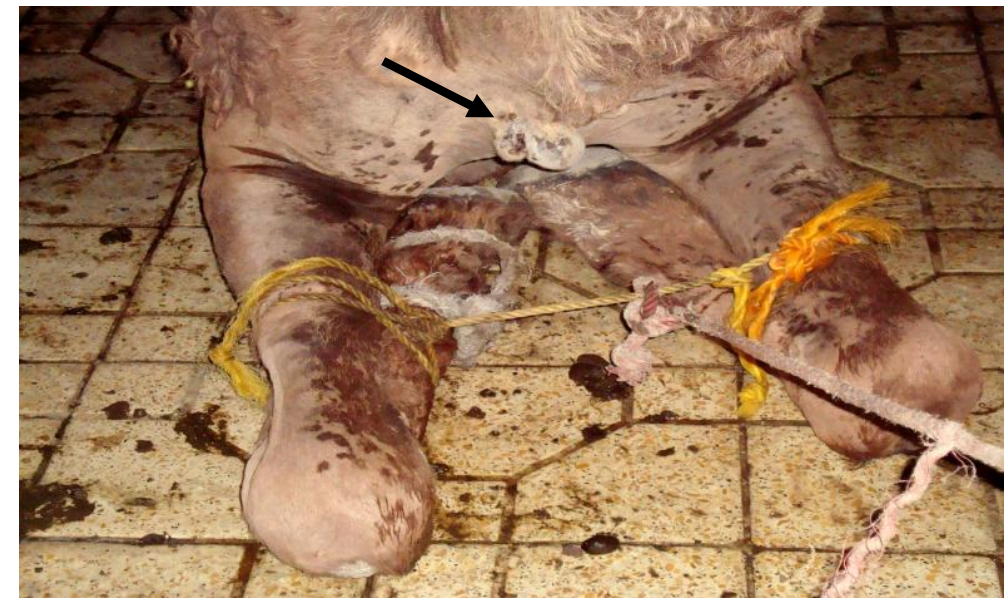

Fig (1): Papillomatosis in 6 years she-camel on the brisket.

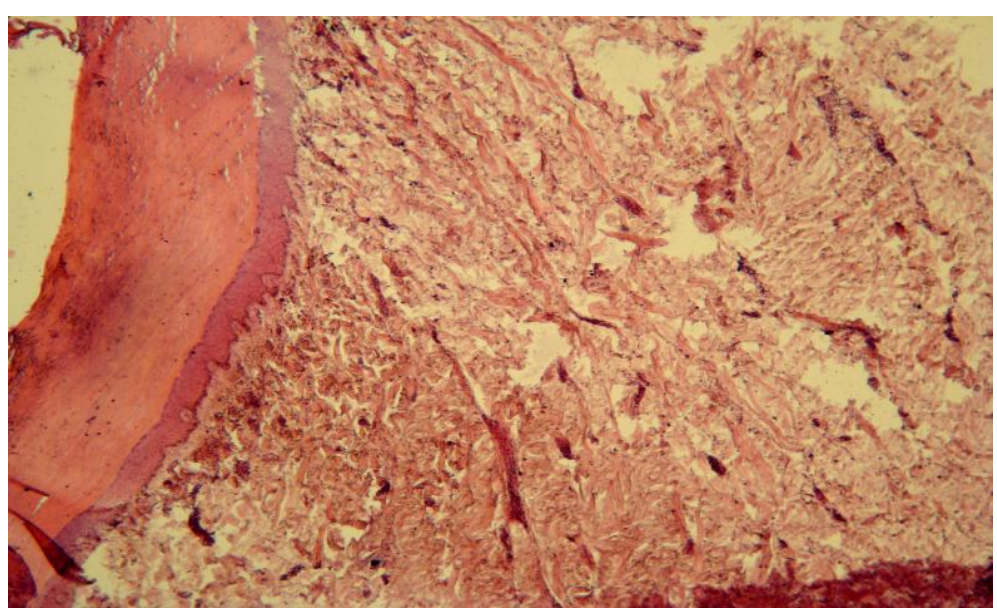



Hematoxyline-eosin stain.

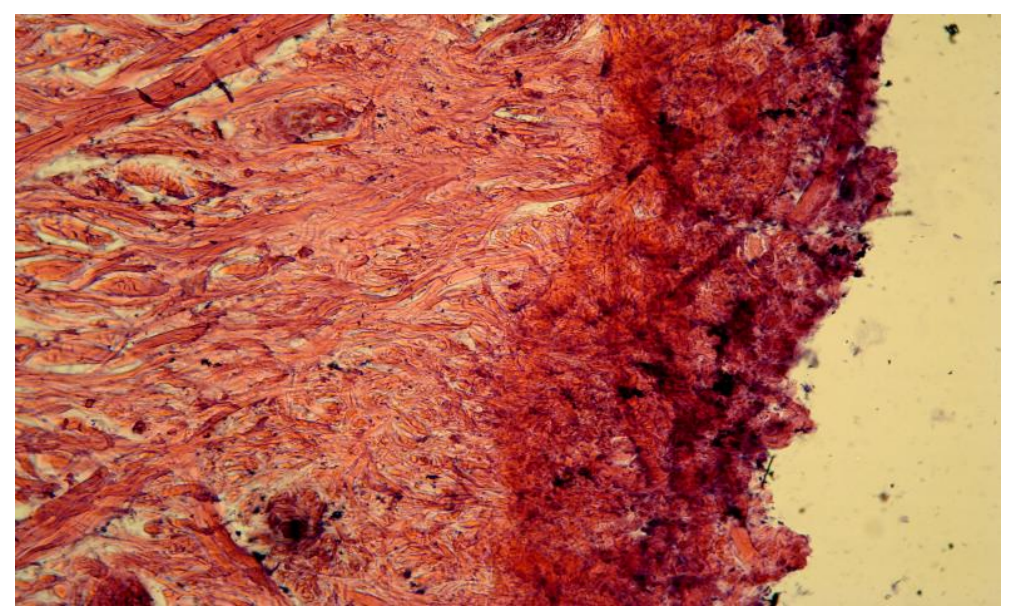

Fig (3): Histopathological section in papilloma isolated from camel. X100 H\&E. Haris Hematoxyline-eosin stain.

Growth of papilloma is slow, painless, and self-limiting is the common prognosis. Young camels less than 5 years old seem excluded from infection. Lack of studies on this disease especially in Iraq may belong to the difficulties in obtaining papilloma because it needs surgical tools to be removed. Besides, surgical removal is not recommended in the early stages because it

1.Munz, E.; Moallin, A.S.M.; Mahnel, H.; and Reimann, M. (1990). Camel papillomatosis in Somalia. J. Vet. Med. B 37: 191-196.

2.Munz, E. (1992). Pox and pox-like diseases in camels. Proc. 1Sitn t. Camel Conference. Eds.: W.R. Allen, A.J. Higgins, I.G. Mayhew, D.H. Snow and J.F. Wade: R. and W. Publications, Newmarket, UK: 43-46.

3.Wernery, U.; and Kaaden, O.R. (1995). Infectious Diseases of Camelids. Blackwell Wissenschafts- Verlag, Berlin.

4.Khalafalla, A.I.; Abbas, Z.; and Mohamed, M.E.H. (1998). Camel papillomatosis in the Sudan. J. Camel Prac. and Res. 5 (1): 157159.

5.Kinne, J.; and Wernery, U.(1998). Papillomatosis in camels in the United Arab Emirates. J. Camel Prac. and Res. 5 (2): 201-205. will stimulate papilloma recurrence; another cause is that camels are roaming animals. Camels seem to be marvelously impervious against diseases comparatively with cattle which look more susceptible to diseases. Few reports regarded to papillomatosis in several countries like in Sudan where several cases have been reported (9).

\section{References}

6.Khalafalla, A.I. (1998). Epizootiology of camel pox, camel contagious ecthyma and camel papillomatosis in the Sudan. Proc. Int. Meeting on camel prod. and future perspectives, Al-Ain, UAE, May 23,1998: 105.

7.Harold, E.A.; David, P.A.; Sir, J. A.; and Franklin, M.L. (2000). The Merck veterinary manual, $8^{\text {th }}$ ed., Integumentary system. Merck and Co., INC., Whitehouse,USA.

8.Bancroft, J.D. and Stevens, A. (1982). Theory practice of histological examination. $2^{\text {nd }}$ edition, New York. Pp: 166-190.

9.Wernery, U.; and Kaaden, O.R. (2002). Infectious diseases in camelids, $2^{\text {nd }}$ revised and enlarged edition. Blackwell Wissenschafts-Verlag GmbH Kurfiirstendamm 57,10707 Berlin. 


\section{الثالول في الابل العراقية \\ سليم امين حسو كلية الطب البيطري/ جامعة بغداد}

\author{
كلية الطب البيطري/ جامعة القادسية
}

\section{الخلاصة}

بدأت هذه الدراسة في كانون الأول 2008 و انتهت في حزيران 2012 في مو اقع مختلفة من ثلاث محافظات;

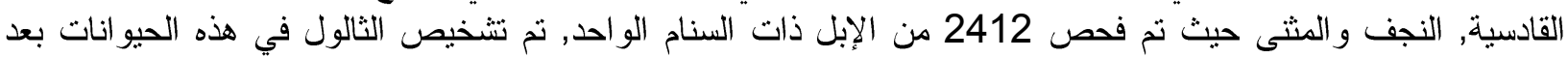

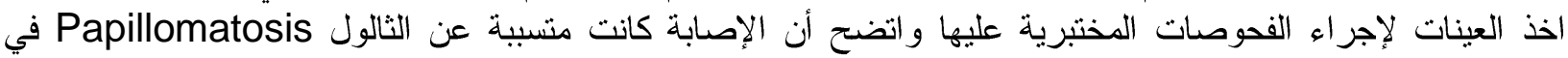

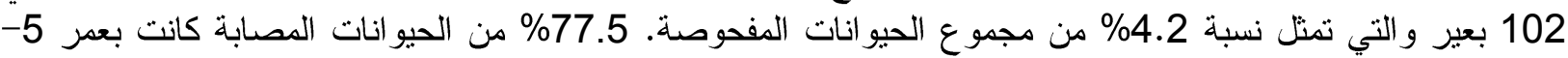

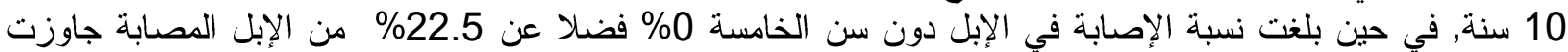
أعمار ها العشرة سنو ات و هذا ما يشير إلى ارتفاع نسبة الإصابة بالثالول في الإبل بعدر 5-10 سنة دون دون غير ها. 